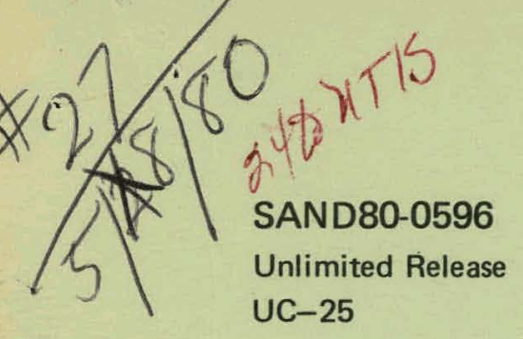

\title{
Metallographic Preparation of Titanium Diboride Coatings
}

Mark E. McAllaster

Prepared by Sandia Laboratories, Albuquerque, New Mexico 87185 and Livermore, California 94550 for the United States Department of Energy under Contract DE-AC04-76DP00789

Printed March 1980

\section{Wandia National Laboratories}




\section{DISCLAIMER}

This report was prepared as an account of work sponsored by an agency of the United States Government. Neither the United States Government nor any agency Thereof, nor any of their employees, makes any warranty, express or implied, or assumes any legal liability or responsibility for the accuracy, completeness, or usefulness of any information, apparatus, product, or process disclosed, or represents that its use would not infringe privately owned rights. Reference herein to any specific commercial product, process, or service by trade name, trademark, manufacturer, or otherwise does not necessarily constitute or imply its endorsement, recommendation, or favoring by the United States Government or any agency thereof. The views and opinions of authors expressed herein do not necessarily state or reflect those of the United States Government or any agency thereof. 


\section{DISCLAIMER}

Portions of this document may be illegible in electronic image products. Images are produced from the best available original document. 
Issued by Sandia Laboratories, operated for the United States Department of Energy by Sandia Corporation.

\section{NOTICE}

This report was prepared as an account of work sponsored by the United States Government. Neither the United States nor the Department of Energy, nor any of their employees, nor any of their contractors, subcontractors, or their employees, makes any warranty, express or implied, or assumes any legal liability or responsibility for the accuracy, completeness or usefulness of any information, apparatus, product or process disclosed, or represents that its use would not infringe privately owned rights.

Printed in the United States of America

Available from

National Technical Information Service

U. S. Department of Commerce

5285 Port Royal Road

Springfield, VA 22161

Price: Printed Copy:

Microfiche:

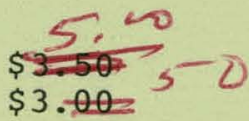




\section{SAND80 -0596 \\ Unlimited Release \\ Printed March 1980}

METALIJOGRAPHTC. PREPARATION OF

TI'TANIUM DIBORIDE COATINGS

Mark E. McAllaster

Sandia National Laboratories

Albuquerque, NM 87185

ABSTRACT

A method is described for preparing metallographic cross sections of thin, hard, chemically vapor deposited titanium diboride coatings on various softer substrates. Standard metallographic preparation techniques were found to result in fracturing and edge rounding of the coatings. It is shown that these prohlems ran he avoided by unidirectional grinding on worn 600 grit silicon carbide abrasive paper. Typlcal photomicrographs of chemically vapor deposited titanium diboride coatings are shown along with photomicrographs of Intermediate phases that form at the titanium diboride - substrate interfaces. 
METALLOGRAPHIC PREPARATION OF $\mathrm{TiB}_{2}$ COATINGS

Thin coatings of erosion resistant titanium diboride are currently being studied by Sandia National Laboratories for application in components ranglng from valve parts in coal liquifaction systems to beam limiters in Tokamak fuston reactors. The $\mathrm{TiB}_{2}$ is chemically vapor deposited as a hard (VHN 3300$) 10$ to $75 . \mu \mathrm{m}$ thick coating on a variety of softer substrates Including steels, copper alloys, iron-nickel alloys and graphite. The major emphasis of the work at Sandia is to characterize the effects of chemiçal vapor deposition parameters on microstructure and erosion resistance of the coating.

Initial attempts to grind and polish cross sections of $\mathrm{TiB}_{2}$ coatings were unsuccessful due to severe rounding and fracturing of the coatings. It is the intent of this paper to describe a procedure that was developed to prepare high quality samples of $T i B_{2}$ coatings for metallographic examination.

The inftial attempts to prepare metallographic samples utilized standard preparation techniques. The samples were sectioned using a diamond wafering blade, mounted in epoxy, ground on 120 thru 600 grit silicon carbide abrasive papers, and polished on nylon cloths using 30 micron, 6 micron, and 1 micron diamond paste. Optical examination revealed that the substrates were adequately polished, however, the $\mathrm{TiB}_{2}$ coatings were fractured with less than $5 \%$ of the coating being sultable for examination. Additional polishIng to improve the condition of the coating resulted in edge rounding to the degree that simultaneous optical examination of the edges and center of the coating was not possible as 11 lustrated in Figure 1 . It was apparent that standard metallographic techniques were inadequate and that an alterHale hethud was needed to obtain a flat highly polished coating. 
As part of an attempt to understand the cause of the fracturing, an assumption was nade that the brittle coating was being fractured, in part, due to insufficient support from the epoxy mount. This assurption was tested by grinding the samples in predetermined directions as illustrated in Figures 2 and 3 . It was found that extensive fracturing occurred at the interface of the $\mathrm{T}^{\mathrm{B}} \mathrm{B}_{2}$ coating and the epoxy nounting material when the samples were heid such that the abrasive parelcles passed from Llie substrate material across the $\mathrm{TIB}_{2}$ coating and 1nto the mounting material as illustrated in Figure 2. Significantly less fracturing occurred when the grinding direction was reversed, as 1llustrated in Figure 3, resulting in more support of the coating. by the stiffer substrate materials which were in intimate contact with the coating. This confirmed the earlier assumtion that the lack of support of the epoxy mount was contributing to the fracturing of the coating. It also revealed that the fracturing rould be minimized by holding the sample tn the proper orientation on the grinding whecl.

This technique allowed a filat surface to be obtalned on the $\mathrm{TiB}_{2}$ coatIng however, a small amount of fracturling st111 occurred as 1llustrated in Figure 4. It was found that all of this fracturing could be eliminated and a high quality, flat, unfractured surface of chemically vapor deposited $\mathrm{TiB}_{2}$ could be obtalned by holding the sample in a stationary position on the same 600 grit silicon carbide abrasive paper for five minutes, as 11lustrated in Figure 5. Any subsequent grinding on new 600 grit silicon carbide paper resulted in fracturing of the coating similar to that shown in Figure 4. Any subsequent polishing using diamond paste resulted $i_{n}$ edge rounding.

A scanning electron microscope was used to examine the new and the worn silicon carbide alsasive papers, Figurcs 6 and 7 respectively, in an effort 
to understand why the worn abrasive paper works well and the new abrasive paper fractures the coating. The new abrasive particles have sharp points and edges, whereas the wọn particles are rounded and flattened. This suggests that the reason the new abrasive particles fracture the coating is that the sharp points and edges of the new particles result in highly streșsed point loading condițions, causing localized fracturing of the hard brittle coating. As the abrasive particles become rounded and flattened this point loading condition is eliminated and the fracturing no longer occurs.

After a high quality polish was obtained, the samples were chemically etched in $2 \mathrm{~mL} \mathrm{HF}, 2 \mathrm{~mL} \mathrm{HNO} 3$ and $96 \mathrm{~mL} \mathrm{H}_{2}{ }^{\mathrm{O}}$. Electrolytic etching in the same solution for up to 100 seconds at $2-1 / 2$ volts was used for the $\mathrm{TiB}_{2}$ on graphite samples. Examination using interference contrast techniques revealed a columar grain sțructure as shown in Figure 8. Banding, apparentiy as a result of filuctuations in gas flow during the chemical vapor deposition prịocess could also bẹ seen in the coating.

Examination of the interface between the $\mathrm{TiB}_{2}$ coating and metallic substrates was performed in a few cases to determine if intermetallics or other borldes were belng formed during the deposition process, Polishing on nylon and microcloths using diamond paste and an oil extender was needed to remove the scratches from the substrate. This polishing was 1 imited to an absolute minimum amount of time due to edge rounding that occurs with longer polishing times. The intermediate phases that formed between Kovar and $\mathrm{TiB}_{2}$ are shown in Figure $y$. These were 1dentifled as $(\mathrm{Fe}, \mathrm{Ni}, \mathrm{Co})_{3} \mathrm{~B}$ and $(\mathrm{Fe}, \mathrm{Ni}, \mathrm{Co})_{2} \mathrm{~B}$ by electron probe microanalysis. 
ACKNOWLEDGMENT3

The author would like to thank Dr. E. Randich for providing the samples and for helpful technical discussions during the course of this work and Dr. J. T. Healey for performing the scanning electron microscopy and P. F. Hlava for performing the electron probe microanalysis. 


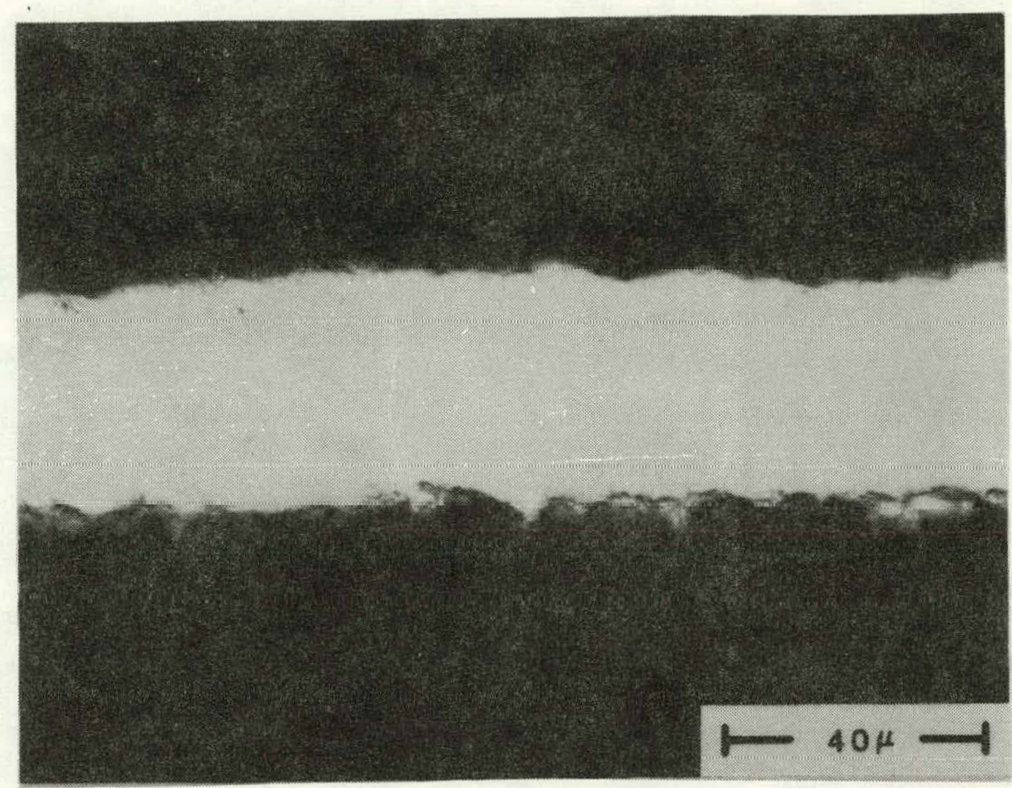

Figure 1. $\mathrm{TiB}_{2}$ coating on graphite substrate showing severe edge rounding as a result of standard metallographic procedures.

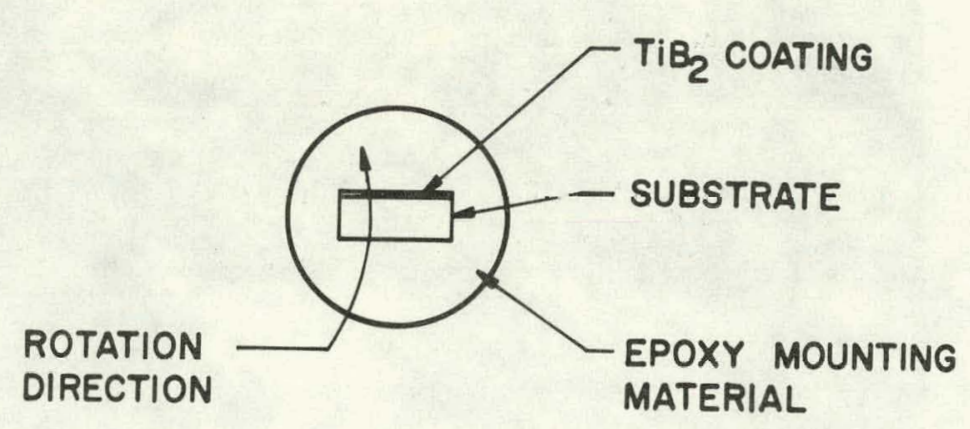

Figure 2. Rotation direction of silicon carbide grinding wheels rosulting in severe fracluring of $\mathrm{TiB}_{2}$ coatings. 


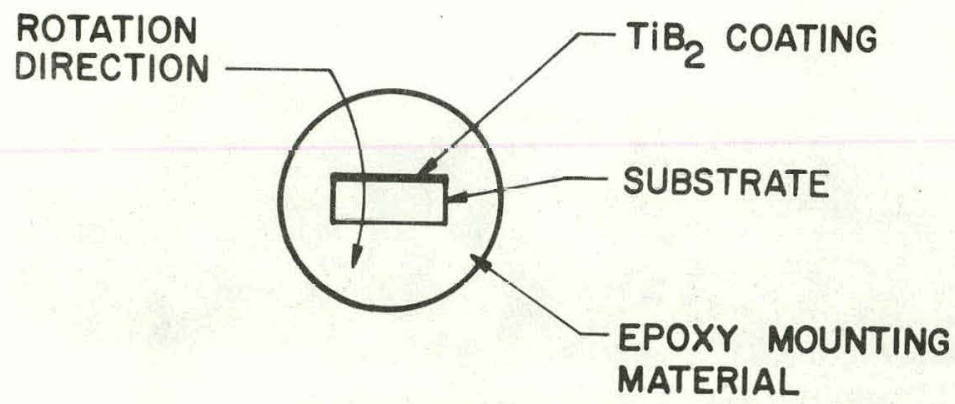

Figure 3. Rotation direction of silicon carbide abrasive wheels minimizing fracturing of $\mathrm{TiB}_{2}$ coatings.

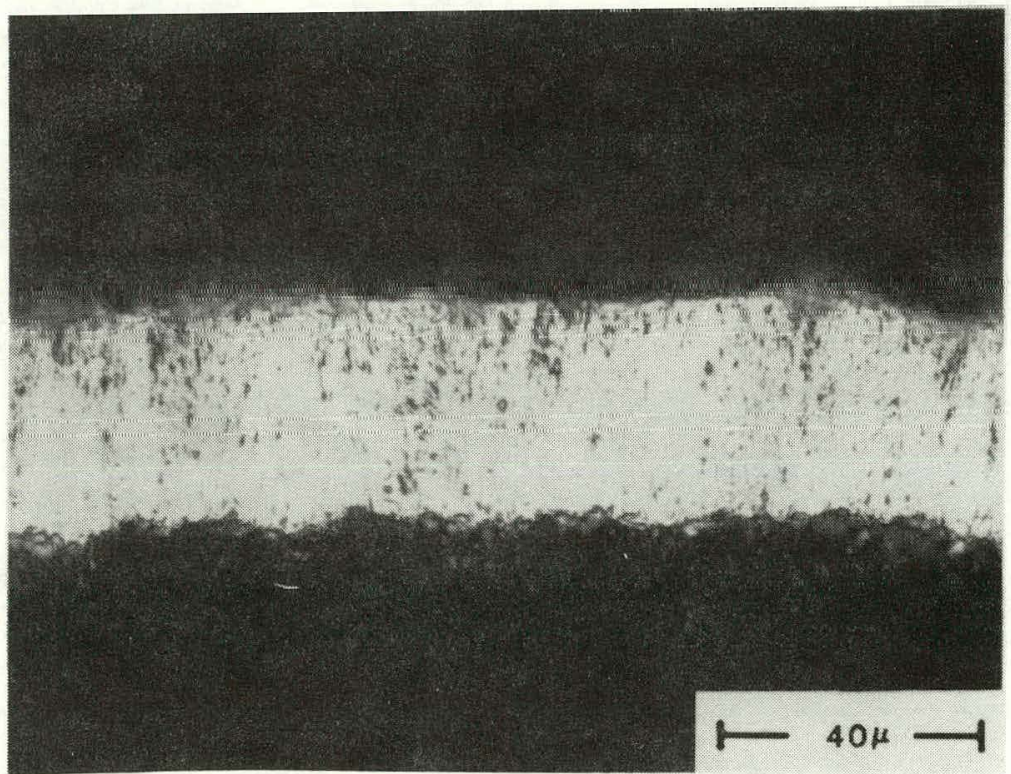

Figure 4. TiB, coating on graphitc substrate showing

flat coating with some fracturing still occurring. 


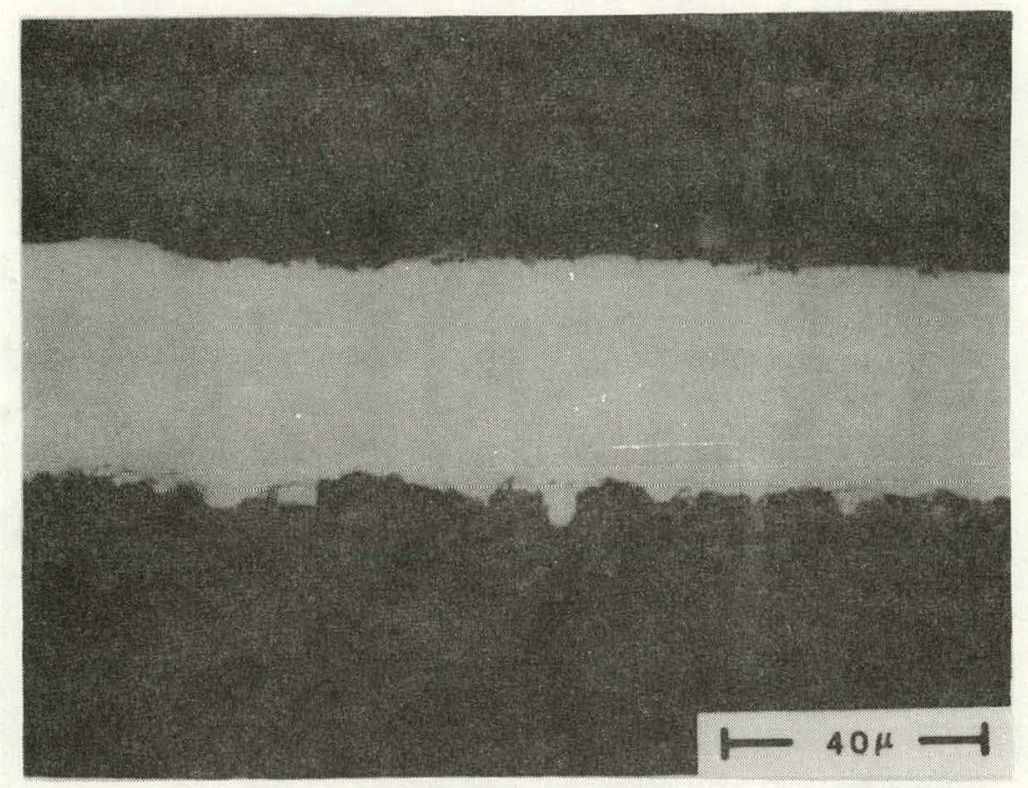

Figure 5. Highly polished, flat $\mathrm{TiB}_{2}$ coating on graphite substrate, no fracturing occurring.

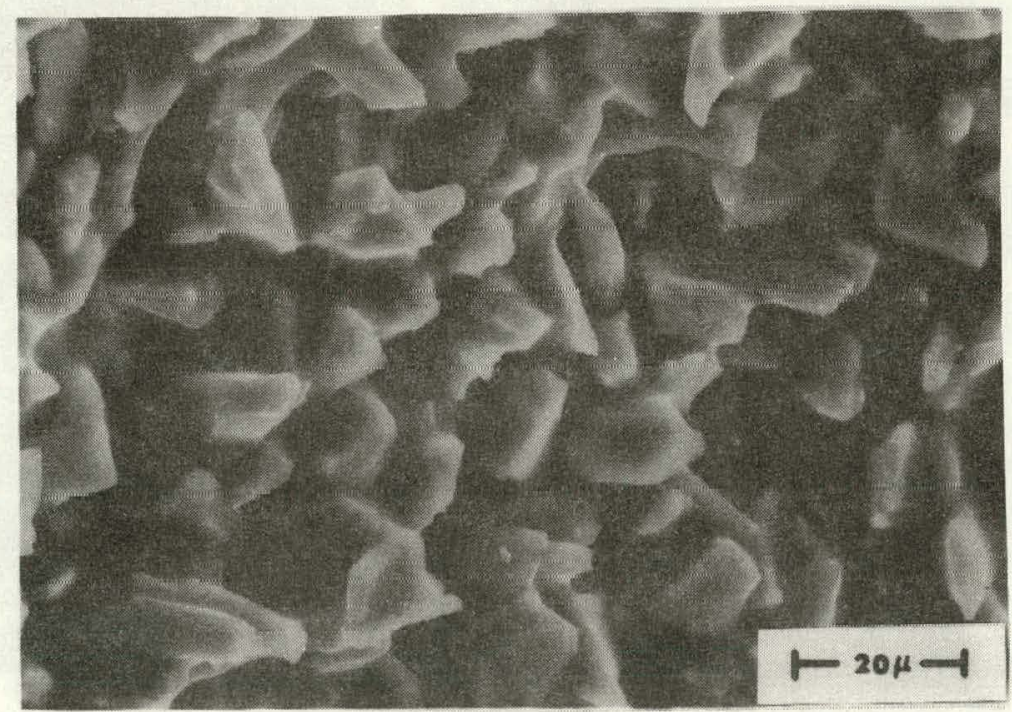

Figure 6. Scanning electron micrograph of fresh 600 grit silicon carbide abrasive showing sharp points and edges that fracture $\mathrm{TiB}_{2}$ coatings. 


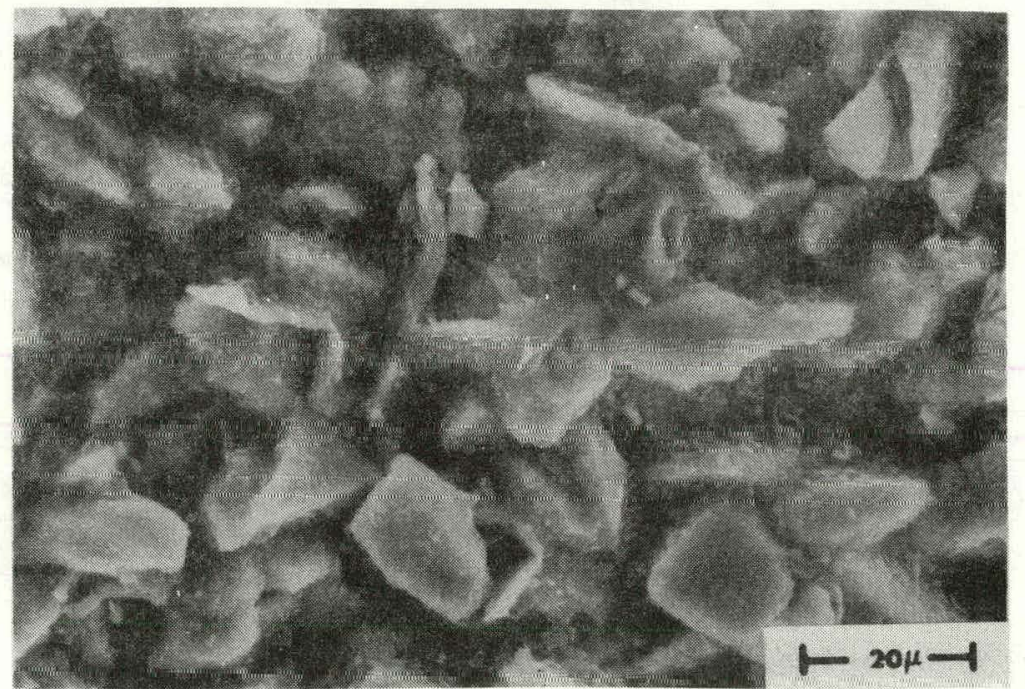

Figure 7. Scanning electron micrograph of worn silicon carbide abrasive showing rounded and flattened points and edges that result in polishing of $\mathrm{TiB}_{2}$ coatings.

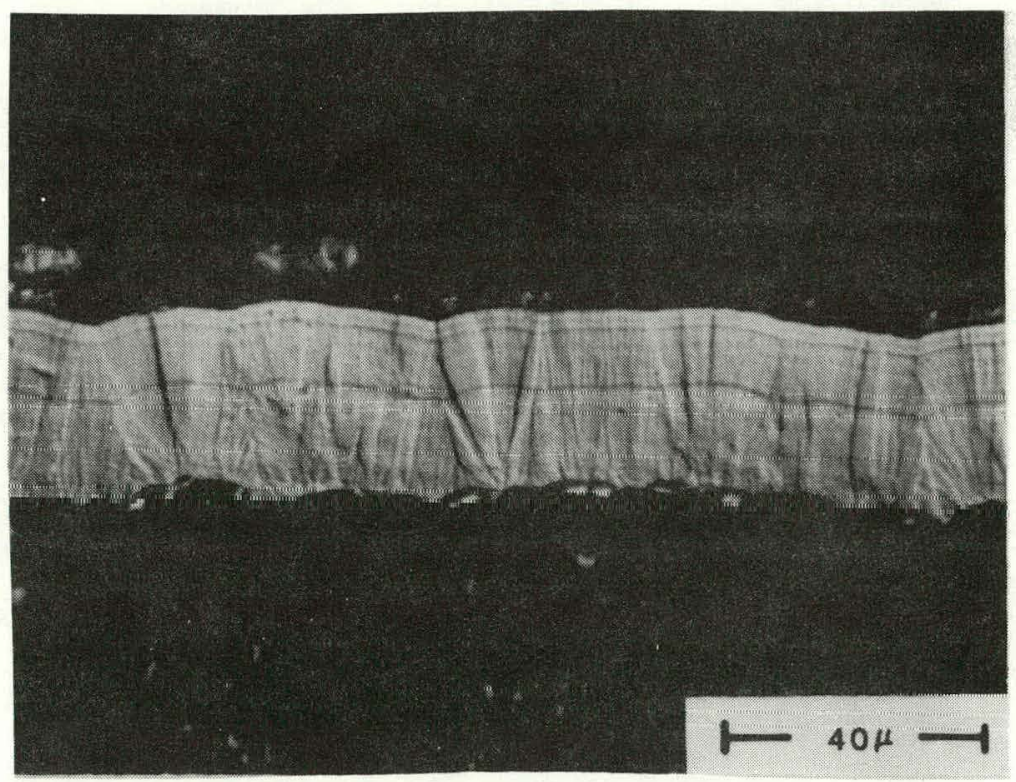

Figure 8. Polished and electrolytically etched TiB, on graphite substrate showing columnar grain structure and banding. 


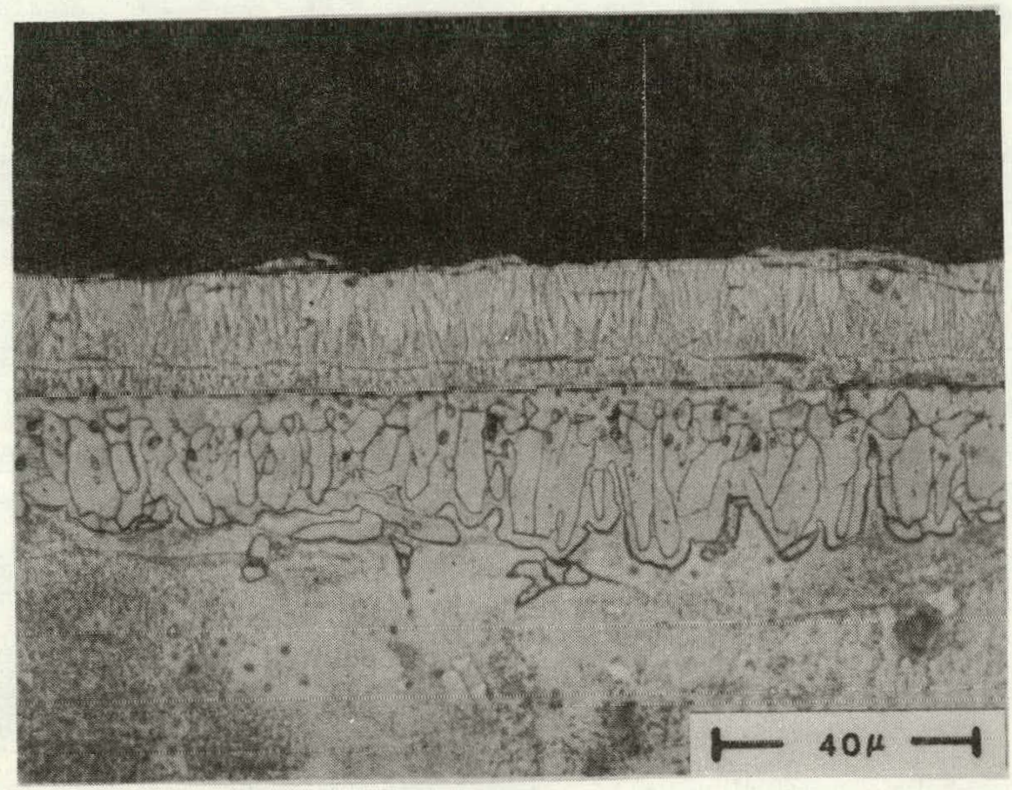

Figure 9. Intermetallic phase at the interface of the $\mathrm{TiB}_{2}$ coating and the Kovar substrate. 


\section{DISTRIBUTION}

5800 R. S. Claassen

(1) Attn: 5810 R. G. Kepler 5840 N. J. Magnani

5820 R. E. Whan Attn: 5821 N. E. Brown 5823 J.A. Borders 5824 J. N. Sweet

5822 K. H. Eckelmeyer

5822

J. T. Healey

T. J. Headley

5822

K. A. Korak

5822

5822

5830

M. E. McAllaster

M. J. Davis Attn: 5832 R. W. Rohde

5833 J. L. Jellison

5834 D. M. Mattox

5835 C. H. Karnes 5836 J. L. Ledman

5834 E. Randich

5834

H. O. Pierson

5834

5834

8312

A. W. Mullendore

J. B. Whitley

8316

W. Hoover

8261-1 T. L. Bryant

LLL

R. Landingham

LASL

T. Jones

BKC

F. A. Clay

3141 T. L. Werner

W. L. Garner

3154-3 R. P. Campbel1

8246

E. A. Aas

(1) 


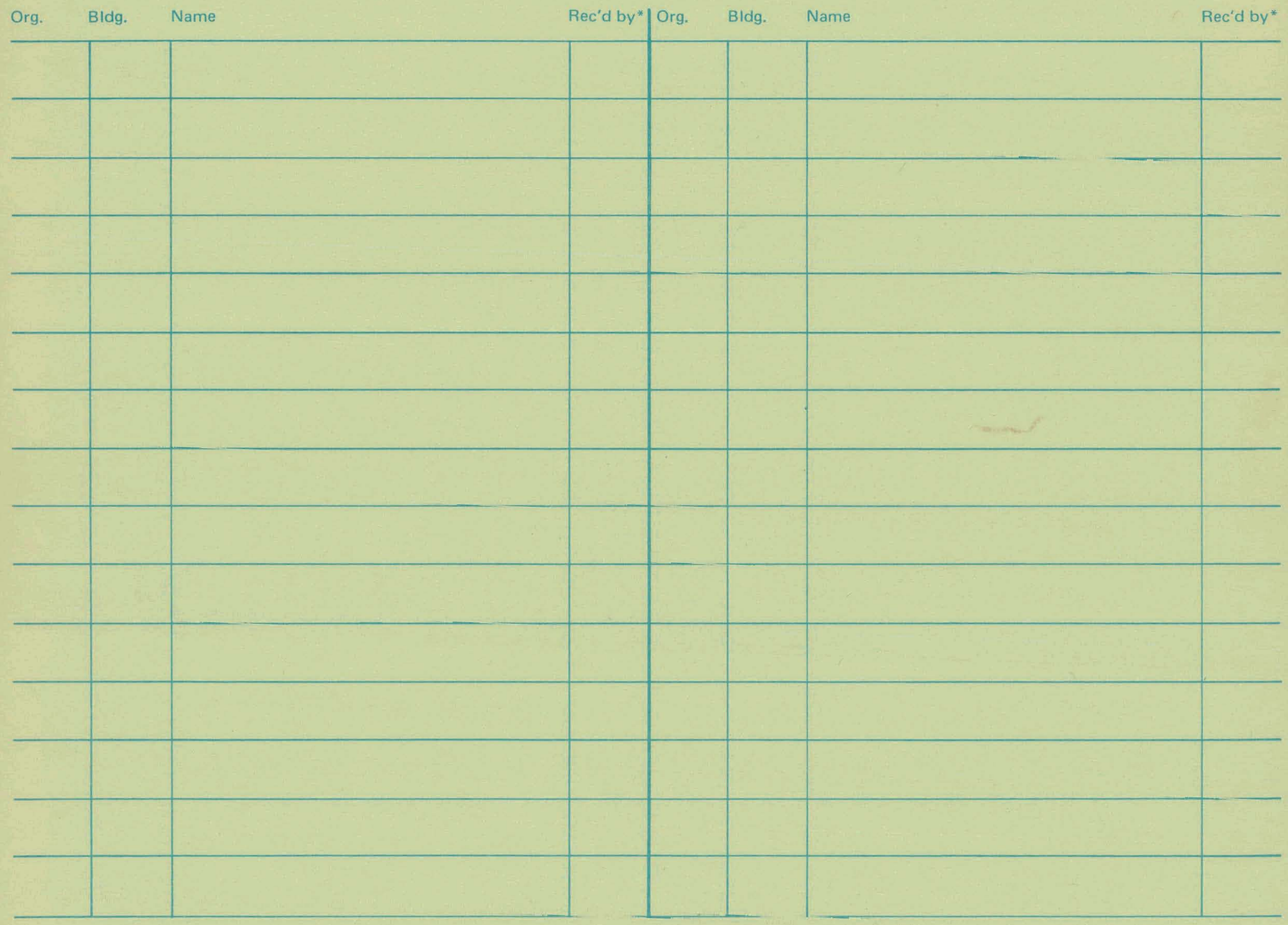

-Recipient must initial on classified documents. 